\title{
New pragmatism pays off
}

\section{Munich}

THE Greens are on the rise again in West Germany. For the first time in two years, a Land (state) government including the Green party was formed in West Berlin on 16 March, pointing the way towards more Green political power. Ten days earlier, national party members elected an executive committee (Vorstand) intent on forming a coalition with the Social Democrats (SPD) in the Bundestag after the 1990 election. The possibility of an SPD/Green coalition is stronger than ever in the aftermath of heavy losses for the conservative Christian Democratic Union (CDU) in recent elections.

Even as their political fortunes are waxing, the Greens are taking a less utopian view toward ridding society of what they see as its technological evils. A survey of Green politicians in Bonn and elsewhere reveals a more pragmatic attitude towards divisive issues such as genetic engineering, nuclear research and space exploration. Once advocates of banning everything to do with technology, ten years of political experience has tempered Green extremism.

The Greens shared power once before in a stormy coalition with the SPD in the Land of Hesse from 1985 to 1987. But a conservative coalition led by the CDU took over, in part because of governmental paralysis on nuclear issues. They faded from view after that, plagued by internal struggles. The election of a pragference in early March reveals the new direction of the party. The three executive committee spokespersons electedVerena Krieger of Witten, Ruth Hammerbacher of Osnabrück and Ralf Fücks of Bremen-were careful to avoid the kind of name-calling that was so destructive two years ago. The election, and the matic leadership at the Green party con-

decision of West Berlin's Greens to form a coalition with the SPD, reflects the wishes of Green voters to see their leaders take action, even if it means compromise.

Because of its unique status, the Greens' success in West Berlin is hard to extrapolate to the rest of the country.

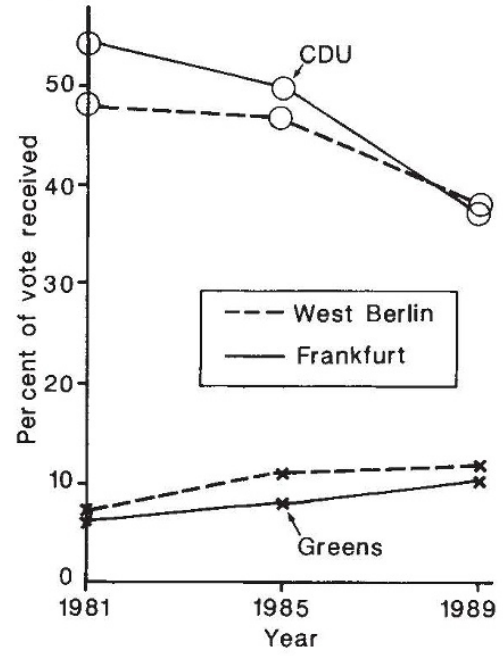

Small but steady progress of Greens.

The Alternative Liste (AL), a local Green party, had always been strong in some areas of West Berlin, which has a large population of draft-resisters and dropouts from society. After weeks of debate, the SPD and AL reached a compromise on governing the city.

But the results of community elections in Hesse on 12 March suggest that the Berlin result was not a fluke. Green support surged all over Hesse and helped topple a CDU government in West Germany's financial capital Frankfurt. A new political constellation seems to be forming which is widely seen as a threat to the re-election prospects of Helmut

ENVIRONMENTAL PROTECTION

\section{Compromise reached \\ Paris}

Delegates from 116 nations meeting last week in Basel, Switzerland, under the aegis of the United Nations Environment Programme, failed to reach unanimous agreement on rules governing dumping of toxic waste. Only 34 nations signed a treaty, which had taken 18 months to draft, but 105 did sign a final compromise document. The United States, Britain and the Soviet Union were among those calling for more discussion before signing a treaty.

Some developing nations wanted a total ban on the export of toxic waste because, they argue, they are easy prey for industrial companies seeking to dispose of waste away from their own back yard. But for most European and other industrialized nations, waste disposal is an acceptable
Kohl's conservative coalition in 1990 . According to a poll taken by the magazine Spiegel in February, Kohl's CDU and its Bavarian sister party CSU had reached a two-year low in popularity.

The compromise worked out between SPD and AL in West Berlin gives some clue as to what sort of science policy to expect in a national SPD/Green coalition. For example, the AL yielded on initial demands to stop construction of a nearly completed nuclear research reactor at the Hahn-Meitner Institute. Receiving a final licence for the reactor from the new environment senator, a member of the AL party, will be difficult, but the SPD is expected to ensure that it will be possible.

National Green politicians are quick to assure that they would not shut down research institutions. "It would be crazy to forbid nuclear physics research", says Bundestag member Otto Schily, "just because the atomic bomb is a danger to mankind'. If the Greens come to power, says Schily, the freedom of research that is guaranteed in the West German constitution (Grundgesetz) "must not be touched". Schily belongs to the more 'realistic' wing of the Greens.

The most visible feature of the West German research scene that would be affected by Green involvement in government is space policy. West Germany's active collaboration in European Space Agency projects has been supported by a publicity-conscious government that seeks as much prestige as possible for its space programme.

Fücks criticized the space programme because of its ties to the military. Given all the ecological goals the Greens have in mind, it would be hard to continue to invest in expensive programmes such as manned space flight. Despite the criticism, it is unthinkable that a new West German government would renege on international contracts signed by its predecessors. Schily categorically excludes this possibility. The Greens still advocate a shutdown of all nuclear plants, and their views are not far from those of the general public in West Germany. Nearly 80 per cent of the population would prefer an immediate or gradual shutdown, according to the Spiegel survey.

Like nuclear power, genetic engineering is an issue that calls for sweeping condemnations from Green politicians. But the current leaders have begun to break from their predecessors in admitting some practical uses for molecular biology, such as the development of AIDS treatments.

Maintaining their political momentum going into the long series of Land elections in 1990, culminated by the Bundestag election, will be difficult. But recent events have ensured that the Greens will not just go away. Steven Dickman 